\title{
Adapting to risk and perpetuating poverty: Household's strategies for managing flood risk and water scarcity in Mexico City
}

\begin{abstract}
Adaptation is typically conceived uniquely in positive terms, however for some populations, investments in risk management can entail significant tradeoffs. Here we discuss the burden for households of coping with, and adapting to, adverse water conditions in economically marginal areas of Mexico City. We argue that households' efforts to adapt in conditions of marginality can come at the expense of households' investment in other aspects of human welfare, reinforcing poverty traps. Both economic theory and social-ecological systems analysis point to the importance of cross-scalar investments and institutional support in breaking down persistent poverty traps. Using data from twelve focus groups conducted in Mexico City, we illustrate how such cross-scale connectivity is failing as a result of lack of trust and transparency, the difficulty of collective action, and the devolution of some responsibilities for risk management from the public sector to the household level. We conclude our analysis by arguing for greater attention to these tradeoffs in public policy to help ensure that adaptation does not come at the cost of more generic welfare gains among the most vulnerable populations.
\end{abstract}

\section{Keywords: Adaptive Capacity, Flooding, Water scarcity, Poverty traps}

\section{Introduction}

The concept of "poverty trap" is used in both development economics and in social-ecological system analyses to describe the existence of a persistent, undesirable system state. In the development field, poverty traps refer literally to intransigent conditions of chronic poverty that prove resistant to interventions to improve welfare. In essence, the condition of poverty itself creates reinforcing feedbacks that maintain that condition over time (Banerjee and Duflo, 2011). Social-ecological systems analysis employs the term "poverty trap" to describe a phase of system dynamics characterized by a lack of capacity for consolidation and connectivity, and thus resistance to change (Carpenter and Brock, 2008). In both literatures, poverty traps are conceived as stable states that are self-reinforcing through internal feedbacks, but that can also be externally reinforced from spillover effects originating at other levels of system organization (Barrett and Swallow, 2006). Consequently, a system's capacity to move toward a wealthier stable dynamic equilibrium, or to remain in a poverty trap, will depend not only on the system's internal capacities, but also on the shocks and transfers from or to other systems and scales.

In this paper we use the concept of poverty traps to focus on the burden of adaptation among economically marginalized households in Mexico City. Coupling the concept of poverty traps with insights into differential capacities for adaptation at the household level, we argue that tradeoffs among investments in risk management (a households' specific capacity) and investments in more general future human welfare (generic capacities) contribute to maintaining poverty traps (Eakin et al., 2014). Our aim is to inform the design of interventions to improve endogenous capacities that can be used to move the system away from poverty traps, while 
also supporting efforts to manage water-related risks. Analyzing focus group interview data, we present the different strategies that households use to manage water-related risk and stress. We situate these strategies in the institutional context of household decision-making to evaluate the implicit and explicit costs associated with strategies that, on the surface, appear to be successful local adaptations to uncertain and adverse conditions. We argue that these adaptations, in the context of the particular institutional environment of Mexico City's water sector, can result in reinforcing the political-economic status quo, undermining the potential for more profound systemic transformation. We argue that the adaptations of households to chronic risk essentially break down feedback mechanisms between residential experience and public sector responsibility, leading to inequity in the burden of risk management that hinders the endogenous investment in the generic capacities - health, income, education -- that are critical to overcome poverty traps.

\section{Poverty and Adaptation}

Income poverty and asset deficiencies are strongly associated with vulnerability to environmental stress. Not only are the poor more likely to reside and work in areas of high exposure to risk, but also the poor tend to have fewer savings and assets at their disposal with which to cope and adapt to stress. Nevertheless, the relationship between poverty and vulnerability to environmental stress is not a simple one (Lemos et al., 2007, 2013; Dercon, 2005; Heltberg et al., 2009).

In the climate change literature, an adaptation - or an action, process, or activity designed to reduce the adverse outcomes (or take advantage of opportunities) posed by climatic variability and change (Smit and Wandel, 2006) -- is typically defined, a priori, as good and desirable if it results in a reduction of exposure or sensitivity to climatic shocks or change (see discussion in Eriksen et al., 2015). Households that lack access to safety nets and formal institutional riskmitigating support programs must address their risk autonomously, or, where collective action is possible, at the level of local communities (Agarwal and Perrin, 2008). Their strategies can involve pooling risk in different ways to alleviate the individual burden of harm: across space (mobility), across time (storage), across assets (diversification), across social networks or households (communal pooling) and through exchange (e.g., accessing storage, mobility, diversification, social networks etc. through markets mechanisms) (Agarwal and Perrin, 2008).

Nevertheless, there may be real trade-offs to adaptation, as effective management of some particular risks may create opportunity costs affecting other forms of investment for future wellbeing (Dercon, 2005). These costs can be substantial: requiring not only financial liquidity, but also bundles of human capital (education, labor, time), social capital (collective action, trust, participation), political capital (ties to actors of greater influence), and material and natural assets ("infrastructure" broadly defined). The "lumpiness" of many investments in risk management also creates significant barriers: it isn't enough to make incremental adjustments to livelihoods and assets; adaptation can require the investment of significant capital all at once (Barrett and Swallow, 2006; Nicol and Kaur, 2008). 
Disaggregating the capacities required for adaptation and adjustment to risk into generic and specific capacities offers analytical traction in the challenge elucidating the linkages between poverty and adaptation (Lemos et al., 2013; Eakin et al., 2014). Generic capacities, such as education, health status, wealth, and information access/use, are those that are associated with an individual or households' ability to manage a wide diversity of stressors and shocks. For example, households with savings and stable income are more likely to have financial assets to invest in measures that will reduce future risk, and can often recover more quickly from shocks (Morton, 2007). Households that are healthy or educated are more likely to be able to flexibly deploy their labor, knowledge and other assets to cope with economic, environmental or other disturbances and respond to opportunities (O'Brien et al., 2009). In contrast, specific capacities are those capacities that are more narrowly focused on mediating a particular type of risk, e.g., use of climate hazard insurance, climate forecasts, ownership and use of infrastructural barriers or defenses, or use of technological innovations designed to reduce its sensitivity to a specific environmental hazard.

It is often assumed that capacity attributes are inherently additive: whether specific or generic, "more is better" (Lemos et al., 2013). However, capacities may not always work synergistically, and it is probable that investments in some capacities entail tradeoffs. These tradeoffs may manifest themselves differently depending on an actor's or community's initial endowments and the institutional context of risk management (Eakin et al., 2014). For example, impoverished households with limited assets facing significant variability in their environment may decide to allocate scarce resources to risk management with the aim of providing some stability in consumption (Heltberg et al., 2009). Yet this investment comes at a cost: they may have fewer assets to invest in those capitals that are only likely to generate adaptive benefits in the longerterm, such as education or health. Poverty traps are defined by these tradeoffs: the priorities of risk management for the impoverished today inhibit the ability to invest in the capacities that would substantially improve both welfare and risk management tomorrow (Barrett and Swallow, 2006; Dercon, 2005).

In social-ecological systems analysis, poverty traps are typically explored through the heuristic of the adaptive cycle (Gunderson and Holling, 2002). The adaptive cycle brings attention to disturbance and shocks, and the capacity of systems (including both social and ecological elements) to reorganize, consolidate and recover. In the adaptive cycle or "lazy eight" heuristic, system dynamics are described as a process of wealth (e.g., biomass, assets, or infrastructure) creation, concentration and connectivity ("k" or conservation phase), often followed by a "collapse" or release phase (" $\Omega$ "), reorganization ("a"), exploitation ("r"), through back into the "k" phase (Figure 1). Here poverty traps are system states that remain in chronic states of low connectedness (or internal controllability) and potential (wealth), in other words, the system is unable to transition out of the exploitation phase ("r") (Fig. 1).

Figure 1: The Adaptive Cycle Heuristic

Source: Derived from Carpenter and Brock, 2008. 
The adaptive cycle is typically used to describe natural-resource based systems, and has been critiqued from the social sciences as inadequately accounting for the political nature of human behavior and social interactions (Davidson, 2010; Pelling and Mauel-Navarrete, 2011; Brown, 2014; Tanner et al., 2014). Nevertheless, the concept of "poverty traps" as described in the adaptive cycle provides both a metaphorical and analytical lens to highlight the inherent political nature of social-ecological system dynamics. Social systems adapt to biophysical variability cognitively by creating rules and identities that organize the distribution of resources (and risks), and enable actions (individual or collective) to differentially reduce and cope with variability via investments in generic or specific capacities. These rules and identities are formed as part of political processes: the negotiation of influence and needs in social spheres (Manuel-Navarrete, 2015). Systems characterized by poverty traps lack the capacity to create the rules and identities to mobilize collective action. As discussed above, internal controllability enables transition to the "k" phase by reducing uncertainty and promoting wealth accumulation. In this sense, generic capacities are not just capacities that allow coping with multiple specific forms of external variability. They are also individual, but relational, attributes (e.g., education) that allow the emergence of internal controllability, change relationships with other scales or systems, and provide access to resources and socially protected positions (protection from uncertainty).

Here the circumstances of Wood's Faustian Bargain are particularly salient (Wood, 2003). Those occupying positions of low potential and low connectedness incur large costs to manage risks even in situations of low environmental fluctuations. Hence the Faustian Bargain for impoverished households: By investing in strategies to manage daily risks in order to guarantee survivability, they are unable to make strategic investments in the social and political capital necessary for improving their future well-being - in the language of social-ecological systems, to raise the system's potential and connectedness. While social action may be necessary to draw attention to their needs and priorities, for some households, collective action comes at a cost of labor, time, and often political debts and obligations. In the worst cases, agency can become subservient to clientelism, political manipulation and exploitation. While such clientelistic relationships can satisfy immediate needs, they rarely enable investment in longer-term security (Wood, 2003: 460). Consequently, interventions from higher levels of organization that reduce uncertainties associated with daily environmental stresses, and thus enable investments in the future, may be a key ingredient of policies aiming at breaking down poverty traps (Green and Hulme, 2005). With additional support from external sources (representing a "positive shock" to their livelihoods, see Barrett and Swallow, 2006) households can be incentivized to make investments in their generic capacities, either because the external sources alleviate their burden of managing risk (e.g., through provisioning of insurance or safety-nets, thus providing specific capacities) or because these sources subsidize investment in generic capital.

In the next section, we present the methods used to collect and analyze our data. We then present the results of our analysis before concluding with a discussion of the significance of these findings for understanding the relationship between adaptation to environmental stress and the implications of these strategies for investment in generic capacities.

\section{Methods and Case-Study}




\subsection{Case-study}

Mexico City is a world megacity with a population over 20 million, housing one-fifth of the country's population and generating one-third of its economic productivity (Ezcurra et al., 2006). The city has one of world's more sophisticated and elaborate systems for water management, which evolved over centuries to address issues of drainage, water scarcity, and flooding (Ezcurra et al., 2006). Elaborate infrastructure and engineering investments have been the principal means of adapting to hydro-climatic risk (Izazola, 2001). However localized flood events continue to represent a significant challenge in the city's 16 delegations, affecting communication and transport, public health, and property (Aragón-Durand, 2007).

Figure 2: Origin of focus group participants and areas of flood risk and water scarcity in three Mexico City boroughs.

In our analysis, we focus on three case studies ("delegaciones" or boroughs) in the city (Fig. 2). All three case studies represent areas that are prone to flooding and water scarcity, and also have high levels of poverty (Table 1). The borough of Magdalena Contreras, on the city's southwestern edge, is the source of the last remaining free-flowing river within Mexico City, the Magdalena River. Here, expanding irregular urban settlements have encroached upon unstable slopes, putting populations at risk of landslides, increasing flood risk and contamination for downstream populations, and posing challenges for water access. The borough of Xochimilco contains the last remnant of a complex system of wetlands that was the basis for traditional agricultural livelihoods in pre-Columbian times. Today, the borough faces public-health issues associated with highly contaminated water and wetland loss to urbanization, as well as difficulties for urban areas to access water infrastructure. With 1.8 million residents, the borough of Iztapalapa is the most populous borough in Mexico City and one of the most impoverished. The borough struggles with adequate potable water provisioning, a condition increasingly aggravated by population pressure, while the capacity of the sewage system is easily overwhelmed in the rainy season, causing flooding.

Table 1: Borough Socio-Economic Profiles

\begin{tabular}{|c|c|c|c|c|}
\hline Indicator & $\begin{array}{l}\text { Magdalena } \\
\text { Contreras } \\
\end{array}$ & Xochimilco & Itzapalapa & Mexico City \\
\hline Poverty (\% of population)* & 30.3 & 28.4 & 37.4 & 28.4 \\
\hline Average Education Level (male)+ & 10.16 & 9.8 & 9.8 & 10.8 \\
\hline $\begin{array}{l}\text { Average Education Level (female)+ } \\
\text { Economically Active Men (\% of population) }\end{array}$ & 9.74 & 9.43 & 9.4 & 10.3 \\
\hline 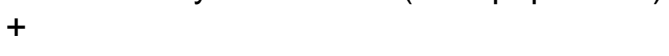 & 59.59 & 62.19 & 62 & 58 \\
\hline $\begin{array}{l}\text { Economically Active Women (\% of } \\
\text { population)+ }\end{array}$ & 40.41 & 37.81 & 38 & 41 \\
\hline $\begin{array}{l}\text { Lack of Access to Health Services (\% of } \\
\text { population)++ }\end{array}$ & 22.1 & 41.6 & 41.3 & 33.57 \\
\hline
\end{tabular}




\begin{tabular}{|c|c|c|c|c|}
\hline Poor Housing Quality (\% of population)++ & 9.8 & 12.4 & 8 & 7.6 \\
\hline Liters of water/Household/Day $\infty$ & 414 & 214 & 238 & 327 \\
\hline Daily Water Access (\% of population) $\infty$ & 78.71 & 69.51 & 69.51 & 81.5 \\
\hline High Level of Urban Marginalization $\infty \infty$ & 11.54 & 30.45 & 20.64 & 10.75 \\
\hline Number of Localized Flood Events (2012) & 18 & 156 & 357 & 3425 \\
\hline \multicolumn{5}{|c|}{$\begin{array}{l}{ }^{*} \text { Poverty defined as a combination of income, education, health and social services, household quality and access to } \\
\text { services, nutrition, and social cohesion by CONEVAL } 2010 \text {. } \\
+ \text { Education level: persons over } 15 \text { years of age. Economically Active: persons } 12 \text { years and over who worked or the) } \\
\text { looked for work in the reference week Census of Population and Housing, INEGI } 2010 \text {. } \\
\infty \text { Jimenez Cisneros et al. } 2011 \\
\infty \infty \text { Impact of the shortages suffered by the population of the urban areas of the country as a result of lack of access } \\
\text { to education, health services, residence in inadequate housing and lack of material goods. (Urban Marginalization } \\
\text { Index, CONAPO, 2010) } \\
\text { - Data from Sistema de Aguas de la Ciudad de México, Unidad Tormenta. }\end{array}$} \\
\hline
\end{tabular}

The 1917 Mexican Constitution considers water as a public good, and in 2003 the Water Law of Mexico City recognized for the first time in Mexico the fundamental right to water. As a consequence of geography, history and politics, there are strong disparities in the availability of water across the city's 16 boroughs (González and Ziccardi, 2012). These differences are based on geographical and geological characteristics, including the presence of local water sources, and the distance to external sources (Perló and González, 2009). Fourteen percent of the population in Mexico City lacks access to water inside their homes and as a result many must rely on water supplied by tanker trucks. Some of these residents are from "irregular" settlements and thus lack hard infrastructure for water and sewage, nevertheless, public authorities are obligated by law to provide a minimal free ration of water. Even where piped water is available, some 1.4 million people in 2006 suffer a lack of water pressure, exacerbated by leakages, and consequently are supplied by the "tandeo system" - where water is delivered during certain hours, two to three days per week (González and Ziccardi, 2012).

The Mexico City Water Authority, SACMEX, manages a vast network of water sources from inside and outside of the city and a complex infrastructure that stores and distributes water to millions of people daily. This implies a significant public investment in drinking water infrastructure projects, maintenance, and new water delivery systems to bring water into the city from neighboring watersheds (Aguirre and Espinoza, 2012). SACMEX monitors water quality for human consumption through the regular testing of wells and water tanks. However, water monitoring and infrastructure investment, and therefore quality, varies throughout the city (Wilder and Romero-Lankao, 2006). For example, from 2007-2012, SACMEX invested \$1 billion USD in different infrastructure works to enhance the quantity and quality of water in Iztapalapa, yet the area continues to suffer from water quality problems (Aguirre and Espinoza, 2012).

In terms of flooding, SACMEX has invested in sewage and sanitation infrastructure through different drainage projects to avoid possible damages and effects. For example, in the period 2007-2012, more than $\$ 5$ billion USD were invested in the construction and rehabilitation of 
pumping plants and "lumbreras" (retention wells), constant dredging and cleaning of drainage, as well as in the construction of large scale drainage systems to remove sewage and rainwater (Aguirre and Espinoza, 2012). However, continual land subsidence from groundwater extraction has overtaken such infrastructural projects, causing infrastructure rupture and preventing a reliance on gravity to move wastewater through the system. Sewer overflows thus are common.

Figure 1: Regions of flooding, water scarcity, and urban marginality in Mexico City.

\subsection{Focus groups}

The data gathered in this analysis comes primarily from twelve focus groups of residents from twenty neighborhoods across the three boroughs ( $n=100$, with an average of 16 per group) (Table 2). The neighborhoods from which residents were recruited were purposely selected as areas most likely to have experienced either flooding or water scarcity, using data on water scarcity from the 2010 National Census of Population and Housing and data on areas exposed to localized flooding, provided by the Mexico City Water System Authority (SACMEX). Recruitment was facilitated with the help of local health promoters.

Table 2: Characteristics of focus group participants

\begin{tabular}{lrrr}
\hline & Participants & \% Female & Avg. age \\
\hline & & & \\
Magdalena Contreras & 26 & 42 & 42.7 \\
Itzapalpa & 36 & 56 & 48.5 \\
Xochimilco & 38 & 76 & 40.2 \\
Total/Average & $\mathbf{1 0 0}$ & $\mathbf{5 8}$ & $\mathbf{4 4}$ \\
\hline
\end{tabular}

Focus groups are a useful method to obtain "combined local perspectives" of certain issues that can help define initial hypotheses to inform further research, and also uncover general patterns and relationships between different processes in particular contexts (Grudens-Schuk et al., 2004). The focus group facilitators structured the discussion around the participants' perspectives on the general situation of water in the city, the challenges faced in their neighborhood (water scarcity and flooding in particular), their past experiences, the strategies and actions they had taken, and their perspectives on the factors that are most responsible for the realities they face. Prior to the initiation of each focus group, we implemented a brief questionnaire with the participants, composed of a total of 20 questions designed to collect information on household water use, costs, and housing conditions, as well as the primary water concerns of the household (Table 3 and 4). The meaning of water scarcity, water quality and flooding was left open for the participants to describe. Water scarcity was typically evoked to describe an unreliable delivery of water and failures in water services such that water was not available when needed and/or rationing was required. Water quality referred to residents' complaints of the smell, color, and turbidity of water such that its use was compromised. Flooding referred to both "encharcamientos" (large puddles, obstructing mobility) and 
"inundaciones" where several feet ( $1 \mathrm{~m}$ or more) of water invaded their neighborhoods and property.

Table 3: Primary issue of concern for focus group participants

\begin{tabular}{lrrrr}
\hline & $\begin{array}{c}\text { Localized small } \\
\text { floods only }\end{array}$ & $\begin{array}{c}\text { Severe } \\
\text { flooding }\end{array}$ & $\begin{array}{c}\text { Scarcity } \\
\text { only }\end{array}$ & \multicolumn{1}{c}{ Mix } \\
\hline Itzapalapa & $3 \%$ & $11 \%$ & $36 \%$ & $47 \%$ \\
Magdalena & $0 \%$ & $41 \%$ & $37 \%$ & $19 \%$ \\
Xochimilco & $5 \%$ & $0 \%$ & $24 \%$ & $70 \%$ \\
Total & $3 \%$ & $15 \%$ & $32 \%$ & $48 \%$ \\
\hline
\end{tabular}

Each focus group was recorded and transcribed, and contextualized with the summary statistics from the questionnaires (Table 3). The transcripts were coded for coping and adaptation strategies, indications of costs and opportunities associated with these strategies, and households' perspectives on their relationship with other actors in their neighborhoods as well as the public sector.

\section{Results}

The discussions in the focus groups centered around the actions and coping mechanisms of the residents in the three case studies as they confronted water scarcity and varying water quality, particularly during the dry season, and persistent flooding during the rainy season. Although the strategies vary in the context of water scarcity and flooding, in both cases the residents have internalized their strategies into their routine daily activities.

Table 4: Questionnaire Results

\begin{tabular}{lrrr}
\hline & Itzapalapa & Magdalena & Xochimilco \\
\hline Live on property without title & $11 \%$ & $59 \%$ & $78 \%$ \\
Original land informal settlement & $33 \%$ & $59 \%$ & $70 \%$ \\
Public sewer connectivity & $97 \%$ & $67 \%$ & $14 \%$ \\
Plumbing for water provision in the home & $92 \%$ & $59 \%$ & $27 \%$ \\
Exposure to water scarcity or flooding & & & \\
Water available all day & $0 \%$ & $30 \%$ & $8 \%$ \\
Water available daily & $14 \%$ & $33 \%$ & $24 \%$ \\
Water always / almost always lacking over the past & & & \\
year & $50 \%$ & $26 \%$ & $51 \%$ \\
Water quality good or very good & $11 \%$ & $59 \%$ & $27 \%$ \\
Flooding always / almost always affects housing \& & & & \\
streets & $56 \%$ & $59 \%$ & $81 \%$ \\
Flooding always / almost always affects housing & $50 \%$ & $44 \%$ & $68 \%$ \\
Flooding always/ almost always affects streets & $89 \%$ & $96 \%$ & $92 \%$
\end{tabular}


National brands as main drinking water source

\begin{tabular}{rrr}
$56 \%$ & $33 \%$ & $46 \%$ \\
$86 \%$ & $22 \%$ & $78 \%$ \\
$69 \%$ & $78 \%$ & $86 \%$ \\
$69 \%$ & $4 \%$ & $59 \%$ \\
\hline
\end{tabular}

\subsection{Scarcity/quality}

The issue of water scarcity and quality affected many focus groups' participants: $80 \%$ reported experiencing water scarcity, where only $23 \%$ reported that they receive water daily, and over a third $(37 \%)$ consider their water as low or very low quality. Residents living in informal settlements are not connected to the water network, and thus depend on water tankers for supplies (over half of the participants in the focus groups live on properties without official title).

Increasing household water storage capacity was the most common strategy described by the focus group participants. Over time, residents have invested in methods of storing water through cisterns or smaller storage tanks (tinacos). Those households with a greater capacity for investment have built large cisterns; others must rely on smaller storage tanks, and hope that those with larger cisterns might share their water if needed. Lack of water at the neighborhood scale also disrupts households' access to health and educational services. Some participants commented that lack of water in the schools has caused periodic school closures, forcing their children to miss classes. The lack of water for sanitation in the health clinics was also confirmed by health care workers who helped recruit participants to the focus groups.

In cases where the public piped water supply is insufficient, or disrupted, residents are entitled to water delivery from public water tankers. Although this delivery system is intended to be free of cost to all residents, the existing norm is for residents to pay a "tip" to the piperos (water tanker drivers) or "they don't give us water". The tip demanded by the pipero can vary depending on the households' urgency of need or the size of the cistern or tinaco. In the focus groups, it was clear that there was no established "tip", and the amounts paid varied widely. Should the public service be slow to arrive or unavailable, residents also can buy water from a private delivery service.

In other neighborhoods on the urban fringe households may tap into local springs through improvised systems of plastic pipes. In these cases, the plastic pipes themselves become a problem: subject to theft and damage, they need constant maintenance. The neighborhoods thus must levy fees and organize collective labor to ensure that the distribution system is maintained. As one resident stated: "The tubing is often stolen and if we don't watch out we end up without water, not just me, everyone." The need for collective action to maintain and monitor the supply system forces the neighbors to impose penalties on those who don't comply, which also incurs time and effort.

Inconsistent and infrequent delivery has led to water rationing in households, in which household members - typically the women - must organize the household to allocate water for different uses and recycle water from one use to another. Several participants compared their 
rationing practices to those with more water in the city: "How much time do you take to bathe? Five, ten minutes? Imagine, we cannot do that, we do not have the luxury." Rationing also occurs temporally, such that households will concentrate household activities involving water into the hours or days where water is available, although this strategy is complicated by the unpredictability of water delivery and can mean that necessary domestic sanitation does not occur when needed.

Despite the established schedule for water delivery for those on the tandeo system, the delivery often does not adhere to the schedule creating a large amount of uncertainty in anticipating water delivery. As a result, residents need to be on call in case the water arrives, in order to open taps to fill their cisterns, tinacos and other recipients, and then to close them when they are full. The hour of delivery can be the middle of the night, or during working hours. If household members work outside of the home they can miss the opportunity to fill their storage tanks. Anticipating and coping with scarcity is also an issue of liquidity. The households may need to pull together a relatively large sum to pay for filling their cistern or tank; they may not be able to save those resources until the moment when water finally is delivered: "in times of scarcity, we might have to wait up to a month and a half for the water tanker; that is, today, we can pay for it today, but it's going to arrive at some point in 45 days!"

Water scarcity is exacerbated by the challenge of poor water quality in many neighborhoods (Table 4). Poor water quality was a complaint not only associated with the water from the tap, but also with water delivered in the public water tankers. The residents described water that was yellow or turbid, smelled foul, or tasted strongly of chlorine, damaging clothes, clogging filters and causing health issues. Households associate both superficial (skin lesions and infections) and internal (viral and bacterial infections) health problems with the water. Health risks are particularly problematic for children: "children are the most affected, since they are the least aware of [water] quality ... they run, do exercise, and anywhere or their own house they fill a class, a bottle of water, and they drink it, without any precaution if it is safe or not." Several residents purchase bottled water for bathing babies because of their fear of potential health consequences.

While purchasing water for drinking is the norm in Mexico City for all economic classes (Jímenez et al. 2011: 74), purchasing water for washing and cooking is an additional burden for these low-income households. Bottled drinking water from national commercial suppliers is more expensive than local water purification and bottling outlets, so residents tend to purchase locally. Nevertheless, they expressed distrust of these local sources, unsure whether they were really getting the quality they were being sold. Thus despite the higher price (over three times that of local bottling operations) $46 \%$ of the participants purchase national brands for drinking, particularly if they have children in the household.

The households were astutely conscious of the tradeoff between their economic conditions and the stability and security of their water supply: "Yes, it affects you economically, because if you have this money for something else, and you don't have water, you have to buy it, and well you have to use the money you were going to use for buying food or something; so yes, it affects 
you economically." Another respondent commented, "Economically it affects us all, because sometimes there are expenses for water that you haven't planned for, they are expenses that suddenly emerge." As one participant noted, "... with the money that we pay, it is money that we could be using for something else and not for paying such a high price for water; that is, for basic family goods...". In short, managing water scarcity under conditions of uncertainty and distrust entails costs that manifest in losses of in generic capacity, primarily in terms of wealth, but also in terms of time, labor and health.

\subsection{Flooding}

When asked about the frequency of damages from flood events during rainy season, $66 \%$ of the participants reported that they sometimes, if not always, experience impacts in their homes or in the streets of their neighborhood. Flooding particularly impacts the daily lives of residents by restricting mobility: overall, $75 \%$ of the participants considered that flooding always or almost always affects their surrounding streets (Table 4).

As in the case of water scarcity, households have made adjustments to their daily lives in order to anticipate and cope with the impact of flooding, although these adjustments are not usually enough to avoid confronting the problems of flooding in their neighborhoods. Participants who had experienced flooding within their homes spoke of the loss of personal belongings including furniture and clothing. While the government offers some financial compensation following floods, generally residents cover the costs of ruined belongings.

Flooding in the home and around the home demands constant attention to cleaning during the rainy season, particularly given the fact that floodwater is typically a noxious combination of rainwater and sewage. It is women who are more likely to be at home to "battle with water". In households where women work outside the home, neighbors or relatives are called on to assist in cleaning, as well as to look for or wait for water in conditions of scarcity. The impact of flooding can translate into lost income when residents must miss work in order to clean the house after a flood event. One resident of Iztapalapa described how most of the neighborhood works during the day, so those at home - often older women -- keep watch for floods and mobilize the residents for action. Others have to miss work in order to clean their houses after floods, which can result in loss of employment.

After some particularly severe events (with residents estimating water levels of a meter or more), many households invested in repairs and improvements: creating physical barriers of plastic or concrete to prevent water from crossing their thresholds, building second stories for their bedrooms and raising furniture on blocks. One resident in an area prone to flooding invested in raising the level of the sidewalk, although he felt that this represented an expense beyond his means and personal responsibility: "... it is what you have to do, pay out what one doesn't have, to put in an apparatus of thousands of pesos so you're not affected again by the flood water." 
Residents sometimes organize in work groups (faenas) to clean garbage and rocks out of drainage areas and fill potholes that turn into large puddles. Explaining that they live in a basin in which both runoff and garbage from higher elevations accumulate, residents in one neighborhood expressed frustration in the difficulty in organizing others in neighborhoods above them. While they could make some headway in keeping their own street clean, they could do little to prevent the garbage from being deposited in the first place. The residents expressed frustration at the lack of government oversight of garbage generated by the weekly street markets and commercial establishments, which tended to accumulate in drains to cause flooding in their streets.

Even when the interior of their house is undamaged, avoiding contact with floodwater outside the home is nearly impossible. Many residents claimed the exposure results in skin irritations since floodwater is often contaminated with fecal matter from the city's combined sewer system. The act of keeping water from entering the home with brooms, buckets and brick barriers also often entailed exposure to water, affecting women more than men. One resident described skin lesions on her son, which appeared after coming in contact with flood water. Another participant commented that many in her neighborhood suffered from anxiety attacks after a particularly severe flood from worrying about the possibility of losing everything again. Repeated anxieties about illness and the loss of material goods have led to general distrust of the public infrastructure and services.

\subsection{Collective action}

In the case of both water scarcity and flooding, residents occasionally will organize as a group to protest and demand better services and infrastructure from public authorities. These actions include demanding action in local borough government offices and blocking roads in protest of the lack of government attention. A resident from Xochimilco commented, "At first they don't pay attention to us... a lot of us have to go to exercise sufficient pressure [on the government] and only then, more or less [do they respond]."

Many residents were ambivalent about the success of these strategies in resolving their problems. One participant explained that in the case of water scarcity, the neighbors have gone to the borough government, but "they do not pay any attention to us. They tell us that they will provide water but it's just talk..." Nevertheless, there were some cases mentioned in which residents had been successful in getting new infrastructure investments in their neighborhoods through their actions, such as a new retaining well or pump installed. And some participants argued that the solution really required bilateral action between residents and the government: "[the solution] does not need to come from one side or the other: it is not solely for politicians or solely for citizens, because if citizens do not respond to government action, then nothing will work."

These mobilization strategies require a significant time commitment during working hours; “... not all of the neighbors cooperate, not all, and the majority work... and the truth is that putting in the papers to improve water services is all well and good, but we just don't have the time." The 
cost, however, of social action and mobilization was not only in terms of the time and effort the residents dedicated to the task, but also in terms of political capital. The participants in the focus groups were aware that the attention they received from authorities was often tied to votes and the political cycle: “...it's when the politicians go looking for votes is when they say they're going to try to fix the water situation ..."

As a result, many of the focus group participants were disillusioned by collective action, and, because of the strategies they had individually pursued, less inclined to mobilize for change: "It's that I think the situation is much of the time out of our control; that is, in our personal situation, we recycle [water], we conserve, we store rainwater and all that, but really resolving the problem is beyond our reach, because unless the authorities want to do something, we can't really accomplish anything... really it is out of our control."

Table 5: Summary of adaptive and coping actions

\begin{tabular}{|c|c|c|}
\hline Action (Adaptation) & Description & Cost \\
\hline Storage & $\begin{array}{l}\text { Tinaco purchases, Cistern } \\
\text { construction }\end{array}$ & $\begin{array}{l}\text { Opportunity cost of domestic labor and } \\
\text { time, Economic investment (\$) }\end{array}$ \\
\hline Barriers & $\begin{array}{l}\text { Threshold elevation; sandbags; } \\
\text { sidewalk construction }\end{array}$ & Infrastructure investment (\$), labor \\
\hline Source diversification & $\begin{array}{l}\text { Purchase from private tankers; } \\
\text { purchase of potable water }\end{array}$ & $\begin{array}{l}\text { Financial investment in water purchases } \\
\text { (\$), time and labor in "looking" and } \\
\text { "waiting" for water }\end{array}$ \\
\hline Collective action & $\begin{array}{l}\text { Demand attention from public } \\
\text { authorities; closing streets to } \\
\text { protest water situation }\end{array}$ & $\begin{array}{l}\text { Time and labor in social organization, } \\
\text { political capital when vote exchange is } \\
\text { expected }\end{array}$ \\
\hline \multicolumn{3}{|l|}{ Action (Coping) } \\
\hline Cleaning & $\begin{array}{l}\text { Cleaning up after flood (home and } \\
\text { street) }\end{array}$ & Health exposure, time and labor \\
\hline Collective maintenance & $\begin{array}{l}\text { Clear garbage from drains; } \\
\text { maintain communal water pipes }\end{array}$ & $\begin{array}{l}\text { Time, labor and financial investment }(\$) \\
\text { health exposure }\end{array}$ \\
\hline Property replacement & $\begin{array}{l}\text { Replacing personal belongings } \\
\text { following flooding }\end{array}$ & $\begin{array}{l}\text { Financial investment }(\$) \text {, anxiety over } \\
\text { losses }\end{array}$ \\
\hline
\end{tabular}

\section{Discussion and Conclusion}

The residents affected by flooding, scarcity and poor water quality describe a diversity of strategies they have pursued to bear and distribute risk in their day-to-day activities (Table 4). Households are situated along a spectrum of specific risk capacities: some with relatively more resources have been able to build second stories to escape flood waters, or invest in large cisterns, or purchase commercial filtered water. Others, in more precarious economic conditions or with less stable tenure, have only been able to use rudimentary risk management interventions and thus were more frequently subject to the impacts of water quality, scarcity, 
and flooding. These strategies illustrate the full diversity of risk pooling strategies outlined by Agarwal and Perrin (2008): through water rationing and storage, they pool risk across time; through diversification of water resources, they pool risk across geography and via market exchange; through cooperation with neighbors, they share the burden of uncertainty in water access and the cost of maintaining infrastructure and recovering from flooding. Together, these strategies are indicators of a significant specific capacity to manage risk locally as well as evidence of individual and community resilience - e.g., "an ability to display positive adaptation despite experiences of significant adversity or trauma" (cited by Brown and Westaway, 2011: 326). Nevertheless, all of these households would be classified as having low generic capacities by standard measures of human welfare: limited financial stocks, low education levels (compared to the potential in Mexico City), chronic health issues, and thus inhibited financially from significantly modify their environments to avoid risk.

It is difficult to empirically quantify the tradeoffs entailed in the households' investments in specific capacities and their investment in the generic capacities such as education, health, and income that would support longer-term welfare improvements. We know that water scarcity, problems in water quality, and flood risk are associated with low-income neighborhoods, and that these neighborhoods are also characterized by challenges in health, education, and opportunity, as demonstrated by census indicators (Table 1). These relationships have been studied, and the inequities in the water system are quite clear (Castro, 2004; Romero-Lankao, 2010; Wilder and Romero-Lankao, 2006; Gonzalez et al., 2011). It is nevertheless very difficult to quantify the relative contribution of water-related problems and, more specifically, the efforts of households to address these problems locally, to the persistence of poverty in these neighborhoods. The data we present here, however, provide qualitative evidence that specific capacities to manage water related risks - i.e., the money, time and labor of poor households -does entail real opportunity costs. These opportunity costs translate into tradeoffs among specific capacity and generic capacity investments: buying water consumes limited cash resources, anticipating water deliveries tie women to the home, organizing to demand improved services requires time away from work and domestic activities.

Generic capacities - wealth, education, health - provide access to social position and political power, which then can be mobilized to enhance the "internal controllability" of circumstances, and to influence higher-level actors to make critical investments to help reduce vulnerabilities (Manuel-Navarrete, 2015; Eakin et al., 2014). In the absence of such generic capacities to leverage collective action, households divert resources to managing risk independently, undermining their ability to build connectedness both internally and with actors with greater power and influence over their structural conditions of their vulnerability. Poverty traps are thus inherently political.

The politics of poverty traps demonstrates the need for specific attention to power and distributional effects of resilience at fine scales in any analysis of social-ecological change, as others have also called for (e.g., Davidson, 2010; Tanner et al., 2014). Generic capacities are relational and often work as social markers conditioning access to resources and risks. How these markers are socially constructed and allocated across the system is in itself a dynamic 
political process (Manuel-Navarrete 2015). While unequal outcomes between species may not be of concern when analyzing transitions from "r" to "K" phases in ecosystems, our case suggests that overcoming poverty traps (i.e., building generic capacities) will likely alter the distribution of power and inequalities between scales or parts of social-ecological systems.

As is highlighted in both the poverty and the socio-ecological literatures, the inability for or ineffectiveness of collective action is a feature of poverty traps. The households we consulted realize they lack "internal controllability" over their environment, and that greater control will only emerge through collective action. Yet from their position of marginality, they express significant uncertainty in the likelihood of success of such action relative to the high cost of social organization, illustrating the painful reality and vicious feedbacks of the poverty trap. In other circumstances these feedbacks can also work to reduce vulnerability: for example, others have documented how neighborhoods with higher concentrations of wealth, political connections and educational attainment are more likely to have more stable and secure water services, and, when these services fail, a rapid response from public sector actors (de Alba et al., 2014). However, as Wood (2003) observed, households lacking capacities for social protection must rely on the capacity and agency of others -- a responsible public authority and the good will and solidarity of neighbors. The residents we consulted perceived that politicians were more interested in their votes than their longer-term welfare. Their lack of faith in the moral contract that should bind the state to its citizens discouraged them from taking the formal steps to demand investments in neighborhood improvements and social services. Instead, their household-level coping strategies have, over time, become individual adaptations aimed at reducing their exposure to risk through their daily routines. In this sense, they are exerting agency primarily in "getting by" through personal, everyday actions, rather than "getting organized" to strategically, and fundamentally alter the conditions of their vulnerability (Brown and Westaway, 2011).

While the data collected in this study was focused on only one level of decision-making and experience (the household), the systems perspective we adopt in this analysis provides avenues to consider cross-scalar processes - e.g., investments and interventions by public sector actors -- in both reinforcing as well as disrupting the conditions of traps (Barrett and Swallow, 2006; Wood, 2003; Carpenter and Brock, 2008). Formal and informal institutional arrangements that serve to lower thresholds for investing in future welfare change and can alleviate some of the burden of risk management, which can be instrumental in altering the persistence of undesirable states. In many neighborhoods in Mexico City, the complexity of formal and informal rules and norms governing water access and flood management complicate, rather than alleviate vulnerabilities. Households face considerable uncertainty in terms of the cost and timing of water delivery, and while flooding is now anticipated in many streets, residents are never sure what the consequences might be of any particular rainfall event. While public authorities may be making substantive efforts for infrastructure improvement, as the focus group participants expressed, the interaction of public authorities and citizens is often contentious and marred by distrust and disillusionment, and many residents feel that their tangible concerns of water scarcity, quality, and flood risk remain unaddressed. 
A particular challenge in the case of Mexico City relates to the adequacy of the 16 borough-level administrations. While these local governments essentially serve to distribute programs and manage basic public services for borough residents, they serve for only three year terms, and often the main agenda at the local level appears to be associated with carving out pathways to higher-level political positions rather than addressing chronic local social and infrastructural problems. Other scholars have documented cases of corruption and private sector-public authority collusion in water delivery, indicating that there may be serious governance issues that must be addressed in the nexus of politics, adaptation, and poverty alleviation (Castro, 2004; Gonzalez and Ziccardi, 2012). Wilder and Romero-Lankao (2006) further assert that effective implementation of more equitable water policy depends critically on the capacity for selforganization, efficiency improvements and sustainability at all scales. As we have noted, the burden of self-organization and mobilization can be difficult for impoverished communities dedicating significant time to managing risk in their domestic sphere.

It is possible that households' strategies to manage the daily challenges of water-related risks may alleviate some of the urgency in the public sphere to resolve these challenges in a way that would enable households to begin to invest in longer-term welfare improvements. Others have noted, for example, the over-reliance of the public sector on individual users to meet their needs and standards for water quality through private means, rather than trust and demand public authorities to provide that service (Jímenez Cisneros et al., 2011: 81; Delgado-Ramos, 2015). At least in terms of water quality concerns, risk management is essentially being transferred or re-distributed from the public to the private sphere with differential implications according to a populations' geographic location and economic capacity (Jímenez Cisneros et al., 2011). In terms of Sapountzaki's classification of forms of vulnerability transfers, resilience of the collective -- Mexico City as a whole -- is reinforced by the vulnerability of the individual (Sapountzaki 2007).

This is not to say that specific capacities or strategies for risk management are lacking at higher levels of organization and in the public sector as a whole. The city authorities are investing huge resources into flood risk management and in improving aggregate water supply for the city; these investments are indicative of the high priority of these issues in Mexico City, and the recognition by the city and federal government of the seriousness of the threat of flooding and water scarcity (Aguirre and Espinoza, 2012). Yet, while some of the more devastating flood events can be at least temporarily avoided through improved dykes, drainage pumps and canals, the scale of these investments does not address the local, chronic vulnerabilities experienced daily in Mexico's poorest neighborhoods, or the inequities in water distribution and use across the city as a whole (Gonzalez and Ziccardi, 2012; Jímenez Cisneros et al., 2011; Castro 2004).

The way forward in addressing these chronic pockets of significant vulnerability in the city requires explicit efforts in the public sector to alleviate some of the cost of adaptation for residents, and, in parallel, efforts to enhance the transparency, accountability and trust among residents and public authorities. The importance of the feedback of information, knowledge, preferences and experience between public authorities and residents is critical in any effort to 
effectively manage risk and vulnerability. Failures in this feedback - illustrating the degree of connectivity in system dynamics -- as when residents lack effective, accessible channels of communication to authorities, and/ or authorities lack the incentives to respond appropriately to residents' needs and interests, can lead to inappropriate or inadequate institutional development and the perpetuation of vulnerability both locally and systemically (Barrett and Swallow, 2006; Wood, 2003).

In face of the complexity of the water resource challenges in Mexico City, these challenges will only be more aggravated in the future with population pressure and environmental change (Romero-Lankao, 2010), and it is unlikely that any one actor group or sector can adequately resolve vulnerability through independent action. The "sustainable adaptation" space must be one in which, for the poorest populations, opportunities for investment in generic capacities are not sacrificed by efforts of risk management (Eakin et al., 2014). Much could be done through public sector action to address the uncertainties associated with the timing of water delivery, enhance the ability of households to appropriately and safely store water, and address water quality through both greater transparency, and necessary technological investments to achieve appropriate water standards. For some wealthier sectors of the city, more individual responsibility for water resource management, conservation, and quality may be required. Perceived and experienced injustice is the root of perpetual conflict between city authorities and neighborhoods; the actions of citizens to close roads and demonstrate in front of government offices are costly and problematic for all involved. Yet clearly residents see little alternative to such action, other than bearing the risks alone. A lack of accessible means for conflict resolution, and for participating in public sector decisions associated with water quality, availability, and flood control also likely exacerbates the problem.

Ultimately it should be in the public interest to alleviate the poverty traps that affect specific populations in the city. Not only are there potentially consequential public health concerns associated with chronic exposure to poor water quality and flooding, but also there is a clear need to facilitate households' capacities to independently invest in their own futures. The residents who participated in our research process were clearly concerned, committed and capable of "getting by." But ultimately it is the capacities for getting organized and getting on that are critical for overcoming poverty traps. Through more explicit attention to the interaction of welfare investment and risk management these capacities can be fully realized among Mexico City's poorest households.

\section{References}

1. Agarwal, A. and N. Perrin, 2008. Climate adaptation, local Institutions, and rural livelihoods. International Forestry Resources and Institutions Program, Working Paper \# W08I-6, School of Natural Resources and Environment, University of Michigan.

2. Aguirre, D. R., and V. Espinoza, 2012. El gran reto del agua en la ciudad de México. Sistema de Aguas de la Ciudad de México (SACMEX), Mexico, D.F.

3. Aragón-Durand, F. 2007. Urbanization and flood vulnerability in the peri-urban interface of Mexico City. Disasters. 31(4), 477-494. 
4. Barrett, C.B., and B.M. Swallow, 2006. Fractal Poverty Traps. World Development, 34(1), 1-15.

5. Brown, K., 2014. Global environmental change 1: A social turn for resilience? Progress in Human Geography, 38, 1007-117.

6. Brown, K., and E. Westaway, 2011. Agency, capacity, and resilience to environmental change: Lessons from human development, well-being and disasters. Annual Review of Environment and Resources. 36, 14.1-14.22.

7. Carpenter, S.R., and W.A. Brock, 2008. Adaptive capacity and traps. Ecology and Society, 13(2), art. 40.

8. Castro, J.E., 2004. Urban water and the politics of citizenship: the case of the Mexico City Metropolitan Area during the 1980s and 1990s. Environment and Planning $A$ 36, 327-346.

9. Davidson, D., 2010. The applicability of the concept of resilience to social systems: Some sources of optimism and nagging doubts. Society \& Natural Resources, 23(12), 1135-1149.

10. De Alba, F., Cruz, C., and O. Castillo, 2014. La informalidad en la hidropolitica: Elementos para estudiar el caso de la delegación Iztapalapa, Mexico, in: de Alba, F. and Amaya Ventura, L. (Eds.), Estado y Ciudanias del Agua: ¿Cómo resignificar las nuevas relaciones? UAM, Cuajimalpa, Mexico, 21-46.

11. Delgado-Ramos, G.C., 2015. Water and the political ecology of urban metabolism: the case of Mexico City, Journal of Political Ecology, 22, 98-114.

12. Dercon, S., 2005. Risk, poverty and vulnerability in Africa. Journal of African Economies 14(4), 483-488.

13. Eakin, H.C., Lemos, M.C., and D.R. Nelson, 2014. Differentiating capacities as a means to sustainable climate change adaptation. Global Environmental Change, 27, 1-8.

14. Eriksen, S., A.J., Nightingale, and H. Eakin, 2015. Reframing adaptation: The political nature of climate change adaptation. Global Environmental Change, 35, 523-533.

15. Ezcurra, E., M. Mazari-Hiriart, I. Pisanty, and A.G. Aguilar, 2006. La cuenca de México. Aspectos ambientales críticos y sustentabilidad. Fondo de Cultura Económica Universidad Nacional Autónoma de México. México, D.F., 286 pp.

16. Green, M. and D. Hulme, 2005. From correlates and characteristics to causes: Thinking about poverty from a chronic poverty perspective. World Development, 33(6), 867-879.

17. González, A. and Ziccardi, A., 2012. Pobreza, escasez de agua y salud en la Ciudad de Mexico. in: Valencia Lomelí, C. F, (Des)encuentros entre reformas sociales, salud, pobreza y desigualdad en América Latina, Tomo II, CLASCO, Buenos Aires, 75-100.

18. Grudens-Schuk, N., Lundy Allen, B., and K. Larson, 2004. Methodology Brief: Focus Group Fundamentals. Extension Community and Economic Development Publications. Book 12. http://lib.dr.iastate.edu/extension_communities_pubs/12

19. Gunderson, L. H. and C. S. Holling, 2001. Panarchy: Understanding Transformation in Human and Natural Systems, Washington, DC, Island Press.

20. Heltberg, R., P.B. Siegel, and S.L. Jorgensen, 2009. Addressing human vulnerability to climate change: towards a 'no-regrets' approach. Global Environmental Change, 19, 8999. 
21. Holling, C. S., 2001. Understanding the complexity of economic, ecological, and social systems. Ecosystems, 4(5), 390-405.

22. Izazola, H., 2001. Agua y sustentabilidad en la ciudad de México. Estudios Demógraficos y Urbanos. 47, 285-320

23. Jiménez Cisneros, B. E., Gutiérrez Rivas, R., and Marañón Pimentel, B., 2011. Evaluación de la política de acceso al agua potable en el Distrito Federal. (Reynoso Gonzalez, Arsenio, coordinator). México, D.F, Universidad Nacional Autónoma de México.

24. Lemos, M.C., Agrawal, A., Eakin, H., Nelson, D.R., Engle, N., and O. Johns, 2013. Building adaptive capacity to climate change in less developed countries. In Asrar, G.R. and Hurrell, J.W. (eds.) Climate Science for Serving Society: Research, Modeling and Prediction Priorities, 437-457.

25. Lemos, M.C., Boyd, E., Tompkins, E., Osbahr, H., and D. Liverman, 2007. Developing adaptation and adapting development. Ecology and Society 12(2): art. 26.

26. Manuel-Navarrete, D., 2015. Double coupling: modeling subjectivity and asymmetric organization in social-ecological systems. Ecology and Society, 20(3), art. 26

27. Morton, J., 2007. The impact of climate change on smallholder and subsistence agriculture. PNAS, 104, 19680-19685.

28. Nicol, A. and N. Kaur, 2008. Climate change: Getting adaptation right. Overseas Development Institute, London UK.

29. O'Brien, K., Quinlan, T., and G. Ziervogel. 2009. Vulnerability interventions in the context of multiple stressors: lessons from the Southern Africa Vulnerability Initiative (SAVI). Environmental Science and Policy, 12, 23-32.

30. Pelling, M., and D. Manuel-Navarrete. 2011. From resilience to transformation: the adaptive cycle in two Mexican urban centers. Ecology and Society, 16(2), art 11.

31. Perló Cohen, M., and A. González, 2009. ¿Guerra por el agua en el Valle de México? Estudio sobre las relaciones hidráulicas entre el Distrito Federal y el Estado de México. Programa Universitario de Estudios de la Ciudad, Universidad Nacional Autónoma de México. México, DF.

32. Romero-Lankao P., 2010. Water in Mexico City: what will climate change bring to its history of water-related hazards and vulnerabilities? Environment and Urbanization. 22(1), 157-178.

33. Sapountzaki, K. 2007. Social resilience to environmental risks: A mechanism of vulnerability transfer? Manag. Environ. Qual. An Int. J., 18, 274-297.

34. Smit, B. and J. Wandel, 2006. Adaptation, adaptive capacity and vulnerability. Global Environmental Change 16(3), 282-292.

35. Tanner, T., Lewis, D., Wrathall, D., and R. Bronen. 2014. Livelihood resilience in the face of climate change. Nature Climate Change, 5(1), 23-26.

36. Tortajada, C. 2006. Water management in Mexico City Metropolitan Area. International Journal of Water Resources Development, 22, 353-376.

37. Wilder, M. and P. Romero-Lankao. 2006. Paradoxes of Decentralization: Water Reform and Social Implications in Mexico. World Development. 34(11), 1977-1995.

38. Wood, G., 2003. Staying secure, staying poor: The "Faustian Bargain". World Development 31(3), 455-471. 


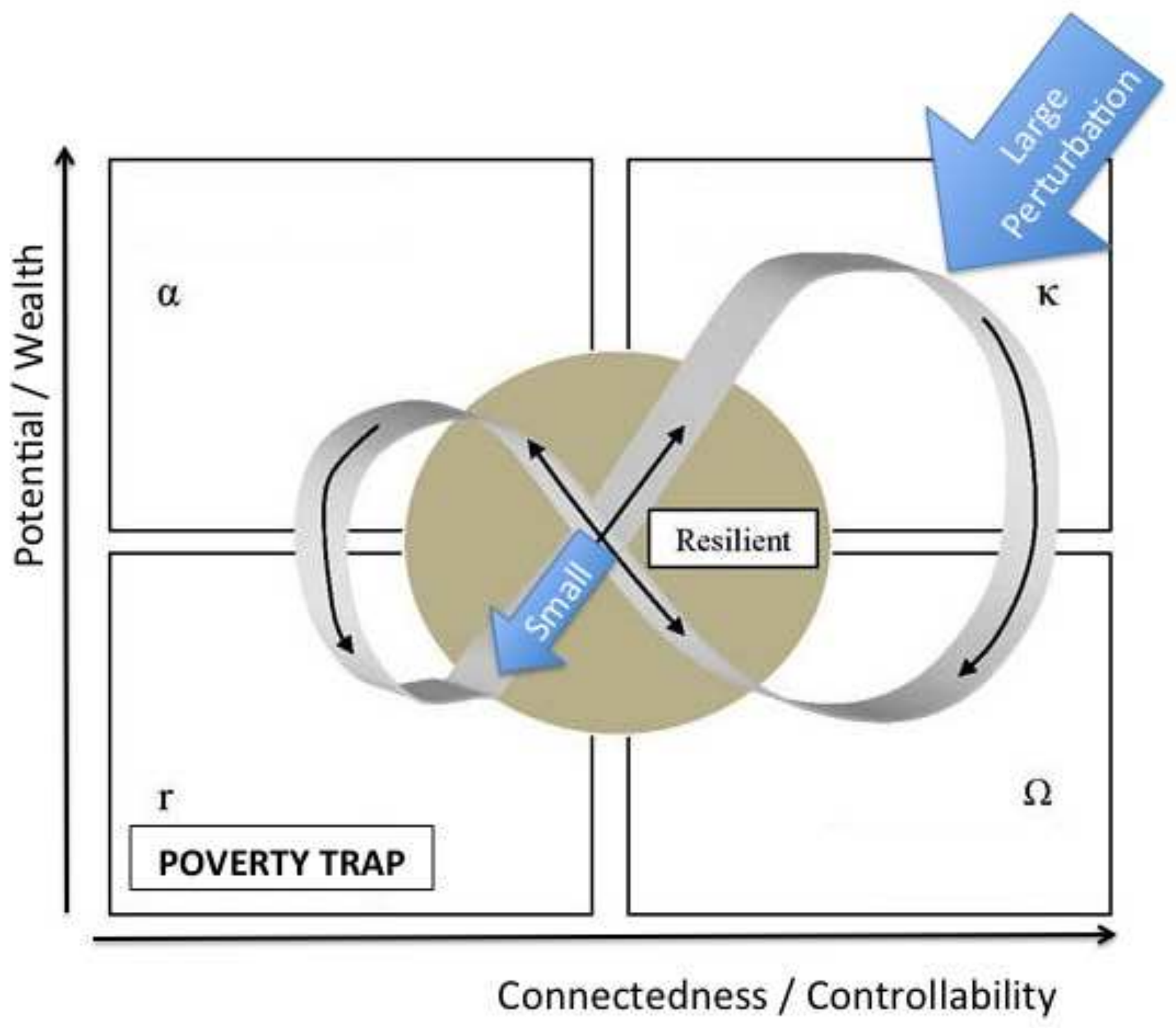




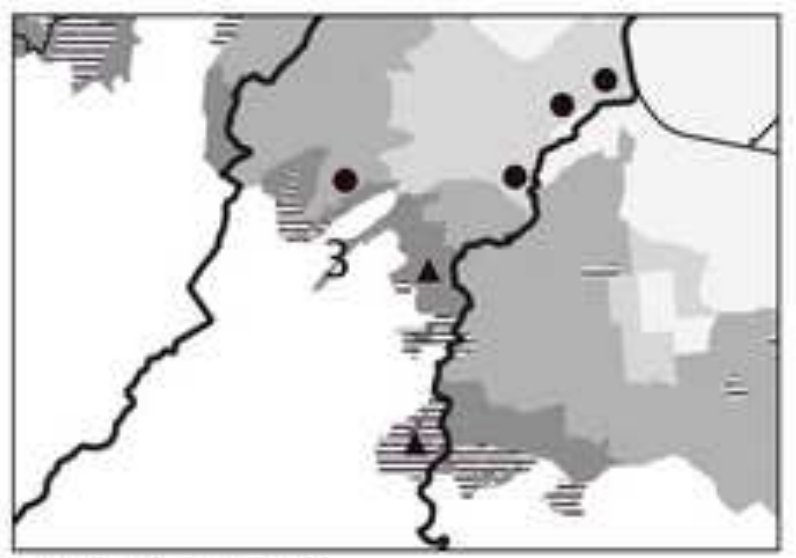

Magdalena Contreras

\section{Legend}

IIIIIII Flooding

三 Scarcity

Focus Groups

A Scarcity

- Flooding
0

10

30

$40 \mathrm{~km}$

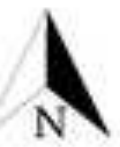

Marginality Index
Very High
High
Medium
Low
Very Low
N/A

1
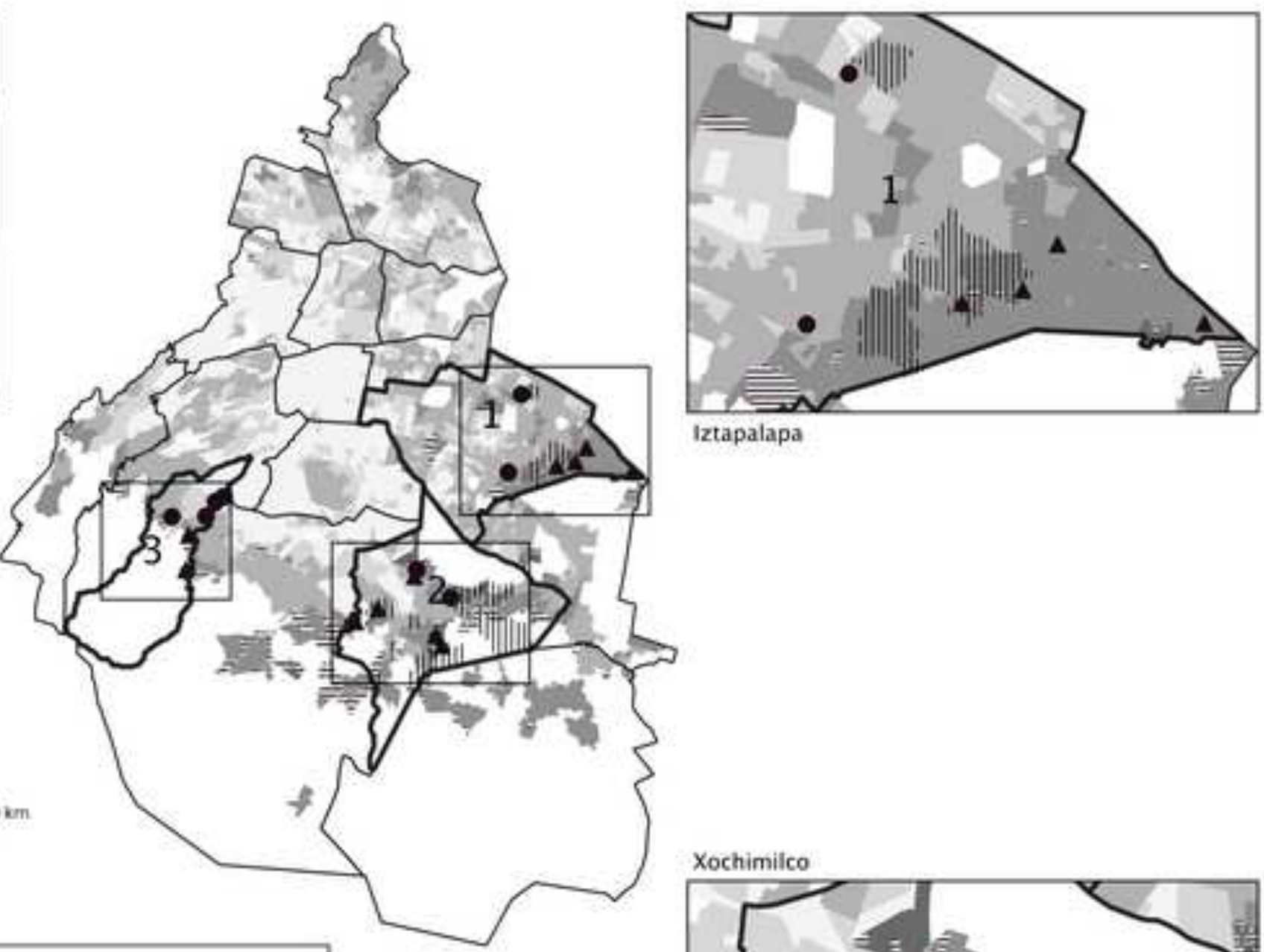

Iztapalapa

\section{Boroughs}

1 trtapalapa

2 Xochimileo

3 Magdalena Contreras

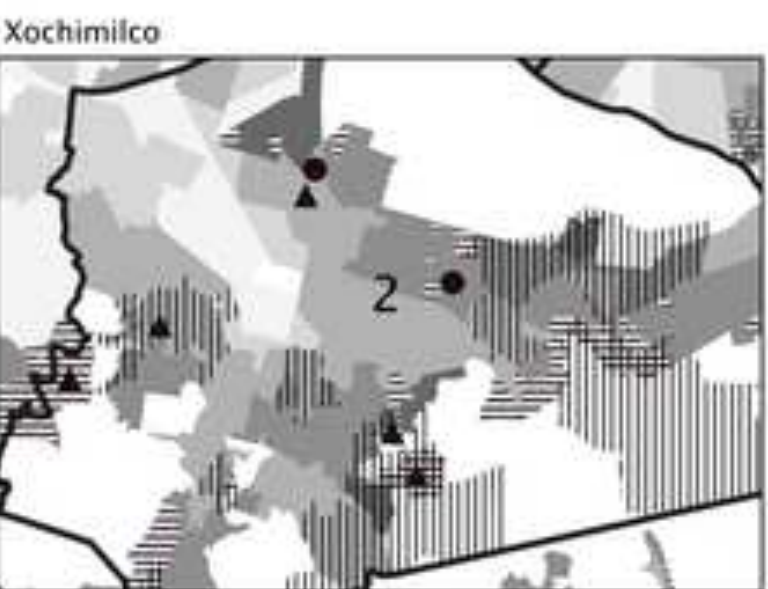

